\title{
Medical Device Report of Prior Investigations
}

National Cancer Institute

\section{Source}

National Cancer Institute. Medical Device Report of Prior Investigations. NCI Thesaurus.

Code C125431.

A report of all prior clinical, animal, and laboratory testing of a medical device. 